\title{
A MORALIDADE NA CONSTITUIÇÃO BRASILEIRA E OS SEUS EFEITOS NA ADMINISTRAÇÃO FAZENDÁRIA
}

Demetrius Nichele Macel

Doutor em Direito pela PUC/SP. Advogado. Professor do Programa de Mestrado em Direito da Faculdade de Direito de Curitiba (Unicuritiba) / demetrius.macei@ unicuritiba.edu.br

Antônio Carlos Diniz Murta

Doutor em Direito pela UFMG. Procurador do Estado/MG. Coordenador do Programa de Mestrado em Direito da Faculdade de Ciências Humanas da Universidade FUMEC / acmurta@fch.fumec.br

\section{Resumo}

O presente trabalho busca identificar o sentido e alcance do Princípio da Moralidade Pública. Utilizando-se do método dedutivo de apresentação do estudo, este inicia traçando um panorama do marco teórico do positivismo, passando pelo pós-positivismo e terminando no positivismo metódico-axiológico de Heleno Torres. Trata da influência do direito privado no direito publico. Aborda a necessidade de controle das decisóes judiciais e do principio-garantia da Segurança Jurídica. Na sequência analisa o princípio da moralidade, relacionando-o a justiça, a igualdade e a legalidade. Em seguida trata do princípio da confiança legitima e finalmente da boa-fé da administração pública, mais uma vez relacionado do com o direito privado, e conclui com aspectos da interpretaçáo das normas tributárias, da moral do fisco e do contribuinte.

\section{Palavras-chave}

Moralidade; Positivismo; Teorema Metódico-axiológico; Confiança Legítima.

\section{Abstract}

This study aims to identify the meaning and scope of Public Morality Principle. Using the deductive method of presentation of the study, it starts by drawing a picture on the theoretical framework of positivism, through post-positivism and ending in methodic-axiological positivism by Heleno Torres. Deals with the influence of private law in public law. Addresses the need for control of judicial decisions and the principle of Legal 
Security. Following analyzes the principle of morality relating it on justice, equality and legality. Then addresses the principle of legitimate trust and finally, comes the good faith of the public administration, again related to private law, and concludes with aspects of tax law interpretation, the moral of the tax authorities and the taxpayer.

\section{Key words}

Morality; Positivism; Methodic-axiological theory; Legitimate trust.

\section{Introdução}

Por mais que a instituição e a cobrança de tributos tenham se aprimorado com o passar dos séculos, trazendo importantes garantias aos contribuintes e também ao Estado, para a satisfaçáo do seu crédito, a doutrina ainda diverge quanto ao papel do tributo na sociedade. Ives Gandra da Silva Martins define o tributo como sendo norma de rejeição social, com destinação maior à manutenção dos detentores do poder, e grande instrumento de exercício do poder por parte destes, com alguns efeitos colaterais positivos a favor do povo, quando há algum retorno de serviços públicos. (2007, p. 06). Em lado oposto, Ricardo Lobo Torres define pagamento do tributo como dever fundamental do cidadáo, norteado pelo princípio da solidariedade do grupo, pela capacidade contributiva e pela finalidade de obtenção de receitas para as necessidades públicas. (2000, p. 321)

Seja qual for o tributo em questão, seja qual for o atendimento dado por ele à capacidade econômica do contribuinte, fato incontroverso é o seu caráter compulsório. Para o sistema tributário pouco importa a vontade do contribuinte, pois a obrigação de pagar tributo decorre diretamente da lei.

Contudo, aprofundando um pouco mais o estudo do fenômeno da tributação, vê-se que, ao contrário do que possa parecer, sua compulsoriedade não é o elemento essencial para o pagamento dos tributos por parte dos cidadãos. A história da civilização mostra um sem número de situaçóes em que a tributaçáo considerada "muito elevada" causou revoluçóes e o rompimento da estrutura existente. É preciso que a sociedade esteja conformada, que aceite ou ao menos que suporte a cobrança. Ou seja: a sociedade precisa aceitar pacificamente tal cobrança e quanto mais justa lhe pareça, mais conformada estará.

Entender que a tributação é elevada trata-se de conceito relativo. A tributação objetivamente baixa pode ser considerada elevada caso o Estado Arrecadador não tenha legitimidade para cobrá-la. A recíproca também é verdadeira. No Brasil fala-se em "carga tributária elevada” em função de quanto a sua receita representa no PIB (Produto Interno Bruto) do país etc. Veja-se que o princípio da capacidade contributiva, entre nós, não leva em consideração este índice. Só é possível invocar a ofensa ao princípio da capacidade 
contributiva se este ou aquele tributo, individualmente considerado foi instituído ou majorado sem observá-lo.

Sob o ponto de vista estritamente jurídico-positivo, pouco importa se a população entenda justa ou injusta determinada imposição tributária, desde que esteja de acordo com as regras de instituição e cobrança previstas na Constituição.

É verdade que a lei não autoriza expressamente a transferência compulsória de patrimônio de dos ricos para os pobres, tão pouco autoriza que algumas pessoas prestem serviços a outras absolutamente de graça, mas, mesmo assim, o Estado intermedia situações como estas, por meio da arrecadação e destinação dos tributos.

Este assunto é objeto de grande polêmica entre os doutrinadores da atualidade, que debatem em que medida essas condutas se adequam ou não à legalidade. Ocorre, no entanto, que o atendimento rigoroso às regras jurídicas também por parte do Fisco não é mais suficiente para que a tributação ocorra de forma legitima.

É íntima a relação entre Direito e Moral. $\mathrm{Na}$ medida em que a ciência do direito assume o positivismo e suas diversas vertentes teóricas, os institutos se distanciam, e mesmo que coincidam quanto aos seus ideais (da prevalencia do bem sobre o mal, do certo sobre o errado, do justo sobre o injusto) a forma de manifestação de ambos é diferente. Para os positivistas, o Direito é amoral. Não cabe ao aplicador do Direito questionar se a lei prevê a conduta corretamente ou não. Atendidas as normas para a instituição de leis, cabe ao legislador apenas alterar o texto da lei, adaptando-o ao conceito de certo ou errado adotado pela sociedade naquele momento do tempo e do espaço, afinal non omne quod licet honestum est.

A discussão toma maior relevância quando o legislador reconhece a Moral como instituto jurídico a ser observado e respeitado, objetivamente. É o que ocorre na Constituição brasileira. $\mathrm{O}$ artigo 37 da Constituiçãao Federal estabelece que a Administração Pública deve obedecer ao "princípio da moralidade". Quando então restaria ofendida tal norma? Esta norma se dirige apenas ao Poder Executivo (Administração Pública) ou também ao legislador? Considerando o principio da legalidade tributária, haveria espaço para o atendimento a moralidade no âmbito tributário?

São poucos os estudos a respeito do tema no Brasil. Antônio José Brandão demonstrou que a moral foi juridicizada inicialmente por meio do Direito Civil, na evoluçáo das teorias do abuso de direito, não locupletamento da coisa alheia e da chamada obrigaçáo natural. (1951, 454-467). Equivalente a isso, no Direito Administrativo, o instituto da moral penetrou no desenvolvimento da teoria do abuso de poder, donde extrai o conceito de que a moralidade administrativa é o "conjunto de regras de conduta tiradas da disciplina interior da administração”. 
Numa concepção moderna, salienta Maria Sylvia Zanella di Prieto, a moralidade administrativa deixou de ser apenas uma questão interna para ser sujeita ao controle do poder judiciário no exame dos casos de abuso de poder, em que o agente age dentro da legalidade, mas com má intensão. Boa parte da doutrina administrativista, ao identificar a má intenção do agente, entende que há na verdade um vício num dos elementos do ato administrativo, a finalidade. E com base nesse entendimento, julgam inválido o ato por ofensa ao princípio da legalidade. (2011, p. 77)

No exame dos estudos desenvolvidos por Heleno Torres, junto ao Universidade de São Paulo, verifica-se um possível método de interpretação e aplicação do princípio da moralidade nos casos concretos, sem um retorno ao superado jusnaturalismo, e ao mesmo tempo buscando no positivismo, por meio de uma visão crítica, encontrar um meio para estabelecer o sentido e o alcance do principio da moralidade no direito tributário.

Sem a pretensão de afirmar total lealdade ao positivismo puro num extremo, ou ao neoconstitucionalismo na sua acepção mais aberta, este trabalho tem o objetivo então de tratar do tema sob as luzes do positivismo metódico-axiológico, fruto dos estudos de Torres, como alternativa na solução dessas questóes.

\section{A Perda de Controle das Decisões Judiciais. O Positivismo Metódico-Axio- lógico}

A grande questão que surge é: num contexto neoconstitucionalista, como prever as decisôes dos juízes, caso eles se utilizem de outros fundamentos para suas decisôes, além das normas constitucionais e infraconstitucionais (tradição romanista) ou dos precedentes judiciais (tradição anglo-saxônica)?

Esses fundamentos poderiam ser, por exemplo, os estudos de Platâo, ou textos religiosos nos estados confessionais.

A tradição positivista definitivamente cedeu lugar a discussóes como estas, pois mesmo que os naturalistas tenham sido superados após a Revolução francesa, tão pouco o positivismo adotado até recentemente atendeu plenamente os anseios sociais de justiça.

Aqui chegamos a um momento realmente crucial. Eros Grau, em sua obra Porque tenho medo dos juizes? já de início constata a realidade em que nos encontramos, isto é, o Estado Moderno. Demonstra que neste Estado opera-se a separaçáo absoluta entre direito posto e direito pressuposto, entre lex e jus. (2013, p. 16).

Cândido Rangel Dinamarco, estudando o que denomina ser o escopo social do processo, conclui que as relaçóes sociais causam frequentemente no indivíduo insatisfaçóes, sentimentos psíquicos que costumam acompanhar a percepção ou a ameaça de uma carência. Essa insatisfação é que pretende o Estado eliminar na sua atividade jurisdicional (2005, p. 12). 
O Estado procura então criar um clima favorável entre as pessoas, um clima de paz social, enfim. Isso ocorre mesmo havendo a parte vencida, pois as partes aceitam a decisão como definitiva e soberana. Obviamente, para ser reconhecida a decisão como definitiva e soberana, e sobretudo ser respeitada pelas partes e terceiros, a mesma deve ser obtida por meio de critérios justos ${ }^{1}$.

É aí que surge o Princípio da Segurança Jurídica, pois diante da impossibilidade de tomar a decisão absolutamente justa, seja pela falta de elementos fáticos, seja pela falta de tempo, desse Princípio (ou sobreprincípio, princípio-garantia) decorrem regras e outros Princípios que buscam o final mais justo possível ao litígio. Daí nascem regras extremamente contundentes sob o ponto de vista da busca da justiça, ou melhor dizendo, da Verdade. Exemplificando: o instituto da revelia, ou da decadência em seus mais amplos aspectos (decadência strictu sensu, prescrição, preclusão), ou ainda da Coisa Julgada.

A Segurança Jurídica privilegia, portanto, a solução da insatisfação gerada pela simples existência de um processo do que o seu perfeito deslinde. Em outras palavras, é melhor terminar com o processo de uma vez, do que eternizar sua existência sem uma solução justa.

Hugo de Brito Machado, citando o jurista português Manoel Domingos de Andrade, salienta que "a vida e o espírito postulam um direito justo, mas pedem também, e antes de tudo, segurança, e portanto um direito certo, ainda que menos justo." A certeza do direito seria então a condição indispensável para que cada um possa saber e avaliar previamente a consequência dos seus atos, garantindo traçar e executar planos de futuro. Conclui que aquele sistema normativo que não tende a preservar a justiça nem a segurança, efetivamente não é Direito. (2010, p. 258-261)

Aqui ilustramos o já anunciado: Se pudéssemos tirar uma fotografia do Direito, veríamos a Segurança Jurídica posando lado a lado com a Justiça, tendo o ordenamento jurídico como pano de fundo. Lado a lado pois, como garantias (Principios-garantia, de Heleno Torres, adiante especificado), não estão sujeitas a sopesamento.

Sob o aspecto do Direito material, também são evidentes as manifestaçôes da Segurança Jurídica. Não só o Juiz, mas também o legislador deve respeitá-la e observá-la ao estabelecer as regras jurídicas. A regulação da vida social também é manifestação do desejo de paz e ordem no seio da sociedade. A Segurança Jurídica pauta a edição das normas jurídicas em geral; leis, decretos, portarias e demais atos legislativos e administrativos, no exercício de seu poder normativo, seja derivado ou originário, respectivamente.

Roque Carrazza ensina que o Direito visa à obtenção da res justa, em que todas as normas, especialmente as que dão efetividade as garantias constitucionais, devem ser

1 Neste sentido também FERRAZ Jr., Tércio Sampaio (2003. p. 313). 
dirigidas a tornar segura a vida das pessoas e das instituiçôes. Estas regras é que garantem certeza e igualdade entre os cidadãos, posto que sabem de seus limites, e sobretudo que os limites são os mesmos do seu vizinho. Tal certeza e igualdade, complementa o autor, são indispensáveis para o atingimento da Segurança Jurídica. ${ }^{2}$

Foi então que Heleno Taveira Torres, com supedâneo na proclamada Segurança Jurídica, desenvolveu seus estudos sobre essas tensóes todas, o positivismo e o naturalismo, o positivismo includente e o excludente da moral, para conceber seu teorema sobre o positivismo metódico-axiológico.

Para TORRES, o Principio-Garantia da Segurança Jurídica é efeito da existência da própria ordem jurídica (2011, p. 63). Mesmo assim, náo pode ser visto como um dado $a$ priori, ou um valor supraconstitucional legitimador do sistema jurídico. Deve, por outro lado, ser construído a cada ato de aplicação do direito, quando os indivíduos e órgãos do Estado cumprem e fazem cumprir as regras do ordenamento vigente.

Sua concepção se aproxima do chamado positivismo excludente, que impóe a separação clara entre moral e direito, mas prefere substituir a expressão por positivismo metódico-axiológico pois, segundo o autor, o positivismo náo deve ser visto como ideologia sobre a justiça, ou como ciência do direito, mas sim como um método do direito.

TORRES evolui a concepção de Joseph Raz de positivismo meramente metodológico, agregando ser preciso acreditar na força axiológica dos princípios e que estes cumprem uma função necessária de acomodação entre legalidade e a realidade, por intermédio dos valores. A norma jurídica pode ser geral, abstrata e constante, mas, no contínuo temporal da sua permanência, seu conteúdo, segundo TORRES, amolda-se a realidade prescindindo de quaisquer correlaçóes entre direito e moral.

\section{A Moralidade Positivada no Texto Constitucional}

Em primeiro lugar: de que Moral estamos tratando?

A doutrina identifica pelo menos quatro sentidos possíveis à expressão "moral”, a saber:

1) Moral como moral individual, que consiste em um conjunto de princípios sobre a conduta humana em relação a ideia que cada um tem do bem e do mal;

2 O autor relaciona também ao Princípio do exclusivismo, pela proibição de uso de normas indeterminadas, ao da vinculação do lançamento à lei, que torna o tributo "pagável”, ao da estrita interpretação da lei, pois fere a segurança jurídica interpretar a lei tributária de forma extensiva, ao da igualdade, que garante a tributação justa, ao da confiança na lei fiscal, em que o contribuinte, confiando na lei, planejará sua vida e seus negócios e, por fim, o Princípio da boa-fé, afeito tanto ao contribuinte quanto ao fisco, gerando segurança jurídica mútua. (Curso...2010. p. 391.) 
2) Moral como moral social (positiva ou convencional), que se define como um conjunto de princípios sobre o comportamento humano em relação a ideia que um determinado grupo tem sobre o bem e o mal;

3) Moral como moral orquestrada, que consiste num conjunto de princípios obtido através de um debate intersubjetivo - sobre o comportamento humano em relação a ideia que a maioria das pessoas tem sobre o bem e o mal. Um exemplo disso seria a declaração de direitos humanos.

4) Moral como moral objetiva (universal, racional, ideal ou crítica) que compreenderia um conjunto de princípios da conduta humana que são justos em si mesmos, sem que sua correção (moral) tenha relação alguma com o que os seres humanos considerem com ou mal. ${ }^{3}$

$\mathrm{Na}$ medida em que igualamos o conceito de ética com o de moral, tratando-os portanto como sinônimos, a concepção adotada não poderia ser diferente a última, ou seja, da concepção de moral objetiva. Assim, vemos o bem ou o mal como o bem ou o mal em si, independente de regras variáveis no tempo e no espaço, tais como regras religiosas ou ideológicas. A tarefa é árdua, mas na visão aristotélica, temos que buscar sempre o "mais excelente" possível.

O princípio da moralidade, então, aparece positivado no texto do art. 37, caput, da Constituição Federal de 1988. O dispositivo legal está enunciado da seguinte forma: "A administração pública direta e indireta de qualquer dos Poderes da União, dos Estados, do Distrito Federal e dos Municípios obedecerá aos princípios de legalidade, impessoalidade, moralidade, publicidade e eficiência [...]".

O legislador, sob influência do direito francês, buscou criar mecanismos que atuem de forma a evitar o desvio e o abuso do poder do Estado, devendo a atividade administrativa primar pela consecução do bem e do interesse público, sendo que para atingir tal fim a atividade administrativa náo pode ser eticamente reprovável (JUSTEN FILHO, 1996. p. 65).

Porém o art. 37 da CF/88 nos leva à uma primeira problemática em sua disposição: a expressa submissão da "atividade administrativa" ao princípio da moralidade. Isto pode nos levar a crer que tão somente a administração pública, enquanto poder executivo, estaria vinculada ao princípio moral, excluindo, portanto, as esferas do poder legiferante e do judiciário. 
O princípio da moralidade como pretendemos reconhecer não está expresso no ordenamento constitucional ${ }^{4}$, assim, a partir de uma interpretação restrita do texto do artigo 37 , se poderia afirmar que restringe-se aos atos administrativos o respeito à moralidade.

Entretanto, Marçal Justen Filho, no artigo publicado a partir de sua explanação no IX Congresso Brasileiro de Direito Tributário, se posiciona contrário a este entendimento. Afirma que tal ponderação não pode ser aceita, em virtude de sua flagrante incompatibilidade com a natureza sistemática da Constituição. No mesmo sentido, cita Garcia de Enterría:

La Constitución asegura una unidad del ordenamiento esencialmente sobre la base de una "orden de valores" materiales y no sobre las simples reglas formales de producción de normas. La unidad del ordenamiento es, sobre todo, una unidad material de sentido [.....(ENTERRÍA, 1991 apud JUSTEN FILHO, 1996, p. 67).

Além disso, JUSTEN FILHO demonstra que tal restrição de aplicabilidade da moralidade (art. 37, caput, $\mathrm{CF} / 88$ ) leva a um vício insanável na interpretação restritiva do dispositivo legal: a edição de normas não estaria vinculada à moralidade, todavia, os atos administrativos realizados a partir de uma lei imoral restariam inconstitucionais, visto que estes sim deverão atender à moralidade pública, ou seja, a lei seria válida, porém imoral, visto que a constituição não veda a criação de normas imorais, entretanto o ato administrativo não seria válido, pois este sim deve atender á moralidade, tornando a lei inócua.

Desta forma, tanto a função de administrar, quanto a de legislar compartilham de conceitos distintos, porém com a mesma natureza de função: a primazia do interesse público (JUSTEN FILHO, 1996. p. 68).

Assim, a "função pública" é exercida concomitantemente por ambas as esferas de poder, seja na edição de normas, seja na aplicação destas. Assim, o vício de imoralidade não se limita tão somente aos atos administrativos, enquanto poder executivo, mas também aos atos legislativos e judicantes, tendo em vista que estes devem ter como norte a Lei e o interesse público. Este entendimento vem sendo defendido ainda por outros doutrinadores, como Cáio Tácito, Maria Sylvia Zanella Di Pietro e Carmen Lúcia Antunes Rocha (JUSTEN FILHO, 1996. p. 69).

\section{Da Autonomia do Princípio da Moralidade}

Os ensinamentos acima nos levam à uma teorização do Princípio da Moralidade, porém se pode identificar uma problemática na proposta de um conceito moral atrelado

4 O Supremo Tribunal Federal, no julgamento do cabimento de Repercussão Geral no RE 579.951 CE, relatado pelo Min. Ricardo Lewandowski, em pronunciamento de lavra do Min. Marco Aurélio, ficou consignado que: A toda evidencia o tema mostra-se relevante, em razão do envolvimento de interesse coletivo. Faz-se em jogo princípio basilar da administração pública que não precisaria sequer estar previsto expressamente na Constituição Federal - o da moralidade." 
ao Princípio da Igualdade: a ausência de autossuficiência da moral para regular as relaçóes jurídicas da sociedade.

Ao adotarmos a ideia de que justiça e moral são conceitos inseparáveis, ainda sim não conseguimos ainda invocar a violação a um preceito moral, sem invocar a violação a outro princípio constitucional, como o da igualdade ou legalidade.

Com base nas ideias de Jürgen Habermas (1997, p. 140), se pode delinear abstratamente este conceito de autonomia de um princípio moral. Para tanto o autor se apoia nas ideias de Kant, que em sua obra "Introdução à Metafísica dos Costumes" afirma que os conceitos fundamentais da moral são redutíveis em três dimensóes: "arbítrio", "relação externa" e "autorização para coerção". Conforme Kant, o conceito de direito não se refere primariamente à vontade livre, mas ao arbítrio dos destinatários, ou seja, lida com a relação externa entre seus sujeitos, e assim recebe autorização para coerção em caso de abuso.

Assim, como também afirma Hart, a legislação moral se espelha na jurídica, por consequência, o conceito de moral se reflete no de legalidade, assim como os deveres éticos nos jurídicos.

Entretanto, em que pese nossa tentativa em dissociar os conceitos jurídicos dos morais, com vistas a autossuficiência deste para regular as relaçóes intersubjetivas, não se pode negar que as normas jurídicas advêm de uma ordem moral, como se estas passassem por um filtro, pois a ordem jurídica somente poderá ser legítima quando não contrariar os princípios morais, assim, o direito adquire sim uma relaçáo necessária com a moral.

Todavia, como bem afirma Habermas, esta relação não subordina o direito à moral, como se houvesse uma hierarquia de normas. Assim, as relaçóes jurídicas e morais enfrentam os mesmos problemas, porém de ângulos distintos: a moral representa uma forma de saber cultural, enquanto o direito, visto como uma simples e prévia convençáo a determinada ação (princípio da legalidade), adquire obrigatoriedade institucional.

Afirma Habermas:

Do ponto de vista sociológico, ambos se diferenciaram simultaneamente do ethos da sociedade global, no qual o direito tradicional e a ética da lei ainda estavam entrelaçados entre si. Com abalo dos fundamentos sagrados desse tecido moral, têm início processos de diferenciação. No nível do saber cultural, as questóes jurídicas separam-se das morais e éticas. No nível institucional, o direito positivo separa-se dos usos e costumes, desvalorizados, como simples convençôes. (1997. p. 141).

Assim, a concepção tradicional de que a ordem jurídica se mostra entrelaçada com a ordem moral, como se houvesse uma relação de cópia entre estes, não perdurou por muito tempo, ou seja, em algum momento na evolução do direito, a moral foi dissociada das normas jurídicas. 
Portanto, não é possível interpretar as normas constitucionais como simples cópias de direitos morais. Os princípios morais, enquanto dissolvido na ordem jurídica explicita um sentido norteador dos juízos práticos, porém ainda em um nível abstrato, neutro em relação às normas jurídicas, pois não se revela em uma efetiva norma de ação, mas sim uma orientação de conduta.

Desta forma, podemos aqui definir que o direito se abstrai da complexidade das relaçóes subjetivas de seus destinatários, limitando-se ao enfoque do modo de agir em conformidade com a regra positivada, levando em consideração membros de uma comunidade abstrata, criada através de normas de direito. Já as normas morais regularam as relaçôes interpessoais e conflitos entre atores que se reconhecem reciprocamente como pertencentes de uma comunidade concreta, ligados através de sua história de vida. (HABERMAS, 1997. p. 147).

Nesse sentido, cabe referenciar a Sacha Calmon Navarro Coêlho (2007, p.239), que traz elucidaçóes quanto ao conceito aqui estudado.

$\mathrm{O}$ autor entende a moral como um sistema que conta com princípios, incorpora a experiência vivida por determinado grupo, de forma a convencer ou reprimir. A moral está no íntimo do homem, atuando sobre sua consciência, de forma a estabelecer o que é certo ou errado, bom ou mau. Apesar de tais expressóes serem um tanto vagas para o tema defendido, no sentido de que um sistema justo pode ser mau, assim como o injusto pode ser bom, conforme demonstrado, cabe aqui evidenciar o caráter subjetivo da moral.

Assim as normas de direito não ligam os indivíduos pela sua identidade pessoal, através de sua história de vida, assim como as normas morais, mas considera tão somente a capacidade deste de assumir determinada postura dentro de uma comunidade instituída juridicamente. (HABERMAS, 1997. p. 147).

Assim, somente é possível regular as matérias que se mostram externas ao indivíduo. $\mathrm{O}$ direito, enquanto conjunto de normas jurídicas, não alcança a esfera subjetiva de seu destinatário, sendo este um dos aspectos fundamentais da legalidade, afastando um princípio moral. A dissociação da moral do direito posto pode ser manifestada pelo Princípio da Legalidade, pois, enquanto aquela leva em consideraçáo o âmbito subjetivo da pessoa, a Legalidade leva em consideração sua ação exteriorizada, estabelecendo um juízo de valoração levando em consideração a ação esperada daquele indivíduo, ou seja, qual seria a ação correta a ser tomada, em conformidade tão somente com as regras válidas juridicamente.

O Princípio da Legalidade está enunciado de diversas formas em nosso ordenamento jurídico: "ninguém é obrigado a fazer ou deixar de fazer algo senão em virtude de lei" (art. 5, II, CF/88), "A administração pública direta e indireta de qualquer dos Poderes da União, dos Estados, do Distrito Federal e dos Municípios obedecerá aos princípios 
de legalidade [...] (art. 37, caput, CF/88), "sem prejuízo de outras garantias asseguradas ao contribuinte, é vedado à União, aos Estados, ao Distrito Federal e aos Municípios: I - exigir ou aumentar tributo sem lei que o estabeleça [...]" (Art. 150, I, CF/88), "Não há crime sem lei anterior que o defina. Não há pena sem prévia cominação legal” (Art. 1aa, caput, Código Penal).

Pode-se notar pela simples leitura destes artigos que todos estes buscaram eliminar o elemento subjetivo na conduta, de forma que não se julga a conduta com base nas vontades e intençóes do indivíduo, mas sim na posição que este deveria ter assumido frente à norma geral e abstrata.

Sob o ponto de vista da complementaridade entre o direito e a moral, o processo legiferante, a decisão judicial institucionalizada, bem como o trabalho da dogmática jurídica, que age de forma a concretizar regras e decisóes, representam um alívio para o aplicador ou julgador, que não precisa ter sobre si o peso cognitivo de formar um juízo moral próprio (HABERMAS, 1997. p. 151).

Porém, aqui não podemos nos conformar com o entendimento de que a legalidade se mostra como um limitador da moralidade, mas devemos retomar à ideia de que tais conceitos são complementares e autônomos.

Conforme exposto, o Princípio da Legalidade, entendido com um sistema jurídico ou de ação, surgiu a partir do momento em que as regras morais perderam sua eficácia, internalizando-se para o sistema jurídico como um padrão orientador de conduta. Isto se deu em razão da perda do reconhecimento recíproco da identidade e história de vida de seus atores com o surgimento dos Estados.

Assim, o conceito de Legalidade se mostra contraposto ao conceito de Moralidade, visto que aquele leva em consideração a posição que o indivíduo deveria ter tomando frente ao evento fenomenológico, desconsiderando o elemento subjetivo. Já a moralidade leva em consideração justamente o elemento subjetivo, ou seja, as motivaçóes do sujeito na realização de sua conduta.

Desta forma, se poderia afirmar que o Princípio da Moralidade é uma exceção ao Princípio da Legalidade, abarcando as situaçóes em que, mesmo atendida a Legalidade, assim como os demais princípios constitucionais, como o da Igualdade, ainda sim teremos uma inconstitucionalidade com base da imoralidade da norma positivada.

Exemplo disso foi o julgamento pelo Supremo Tribunal Federal da Ação Direta de Inconstitucionalidade 4.180/DF (Seção Plenária de 11.09.2014 - Rel. Gilmar Mendes) que reconheceu ofensa aos princípios da impessoalidade e da moralidade por parte de lei distrital. De fato, em análise detida da decisão, percebe-se que mesmo expressamente mencionada a ofensa a moralidade, tratou-se na verdade apenas da impessoalidade. Neste 
caso a questão poderia ser resolvida perfeitamente pela teoria da validade das normas de Kelsen, pois o dispositivo legal não foi suficientemente abstrato, isto é, a lei no seu texto especificou o seu destinatário, pecando em detrimento aos demais cidadãos, fragrantemente privilegiado alguns.

Sem entrar no mérito desta decisão, o que chama a atenção no julgado foi a utilização das expressóes "constitucionalidade formal", referindo-se ao processo legislativo (legalidade) da norma atacada que, segundo a decisão, foi correto, e em seguida a "inconstitucionalidade material" que aí sim afastou-se da legalidade para atacar a impessoalidade e a moralidade, tratando-os como absolutamente autônomos e feridos.

\section{0 Princípio da Confiança Legítima}

A teoria interpretativa de Hans Kelsen é um desdobramento rígido dos pressupostos epistemológicos que orientam o seu método científico, que isola cirurgicamente o objeto mediante o postulado da neutralidade. Resta claro que a sua retomada serve como ponto de partida para todos os doutrinadores que, como Heleno Torres, refletem sobre o intrincado processo interpretativo do direito, aproximando-se das premissas kelsenianas. Todavia, alegaçóes de arbitrariedade e alienação em relação a outras searas do conhecimento são frutos, no mais das vezes, de uma análise superficial ou parcial de suas obras. Não se pode negar o caráter democrático esposado pelo mestre de Viena, que, dentre suas várias obras, se dedicou a temas como a teoria política, ética e moral.

Neste contexto, TORRES apresenta o chamado Princípio da Confiança Legitima, como sendo uma das funçóes que consagram o Princípio da Segurança Jurídica, ao lado da Certeza e da Estabilidade Sistêmica, necessários para conferir conteúdo e concretude à Segurança Jurídica. Em outras palavras, para que o Princípio possa ser efetivamente exercido pelo sujeito destinatário da norma (o cidadão). (2011, p. 196).

A Certeza e a Estabilidade, ou Confiança lato sensu são conferidas pelo ordenamento jurídico, enquanto a Confiança stricto sensu provêm da experiência.

$\mathrm{O}$ autor portanto, mesmo admitindo que a Confiança em sentido estrito decorre dos princípios constitucionais da administração pública, especialmente da moralidade e o princípio (fundamental) da boa administração, procura estabelecer critérios de controle de constitucionalidade e legalidade da Confiança que convenciona chamar de testes de segurança jurídica. Estes testes, porém, restringem-se aquelas primeiras funçóes da confiança em sentido amplo, ou seja, a estabilidade e a certeza, que são ligadas intimamente a legalidade.

Portanto, uma vez aplicados e infrutíferos os testes de segurança, resta então verificar se há no caso concreto a ofensa a confiança em sentido estrito. Aqui temos o retorno a origem do tema em estudo. Temos novamente o entrelaçamento da legalidade com a 
moralidade, este com seu conteúdo próprio e inegável, cujo amálgama seria então a Confiança Legítima do contribuinte nos atos da administração em geral.

Um possível exemplo da realização deste teste podemos identificar em decisão do Supremo Tribunal Federal, no julgamento do RE 601.088/RN, que afastou a aplicação de multa moratória, com fulcro na conjugação do princípio da segurança jurídica com a regra do art. 112 do CTN. Para tanto, reconheceu a configuração de dúvida pela existência de "instabilidade da jurisprudência" quanto à inclusão ou não de determinada verba trabalhista na base de cálculo do Imposto sobre a Renda. ${ }^{5}$ A oscilação jurisprudencial, indiscutivelmente, constitui fator originador de dúvida no Sistema Tributário brasileiro.

Mas se é possível então aplicar isoladamente o princípio da moralidade, passados os testes de segurança da estabilidade e certeza, qual o critério para evitar a subjetividade na aplicação desse princípio?

Entendemos que a resposta pode estar no instituto modernamente denominado BOA-FÉ OBJETIVA, por parte dos agentes da administração pública.

\section{A Moral do Fisco e a Moral do Contribuinte}

Analisando a moral no âmbito tributário, Klaus TIPKE6 dispóe: "A Ética Tributária é por conseguinte a Teoria do agir moral-impositivo dos Poderes Públicos - o Legislativo, o Executivo e o Judiciário - assim como do agir moral-tributário do Contribuinte”.

Assim para TIPKE a ética está atrelada ao agir moral tanto dos poderes públicos, quanto dos contribuintes, ou seja, se refere as condutas adotadas por ambos dentro da relação jurídica tributária, seja na instituição e exigência do tributo pelo sujeito passivo (União, Estados, Municípios e o Distrito Federal), seja no dever fundamental de pagar os tributos pelo sujeito passivo (contribuintes e responsáveis).

Também destaca que as condutas dos contribuintes são influenciadas pela conduta dos agentes públicos, o que há muito tempo já foi contemplado por Aristóteles no Livro II da sua obra Ética a Nicômaco, ao tratar da atividade legiferante aponta que os legisladores tornam os cidadãos bons cidadãos habituando-os a agir bem - é este de resto o seu propósito. E todos os legisladores que não tiverem em mente esse propósito erram. É nisto, precisamente, que se distingue uma boa constituição política de uma má. (2009, p. 41)

Refletindo os ensinamentos de Aristóteles verifica-se que o comportamento dos cidadãos são determinados pelas virtudes dos seus legisladores, que devem lhe imprimir

$5 \quad$ 2a Turma, Rel. Min. Joaquim Barbosa, out.2011.

6 TIPKE. Klaus. Moral tributária do estado e dos contribuintes, 2012, p. 7. TIPKE utiliza as expressôes ética e moral como sinônimos. 
bons hábitos por meio das normas, e ainda ressalta o autor que o legislador que não logra a obter tão êxito, falha no desempenho da sua missão, pois, conforme ele próprio ressalta: "nos tornamos justos praticando açóes justas, temperados, agindo com temperança, e finalmente, tornamo-nos corajosos realizando atos de coragem". Assim, a virtude do legislador consistirá em desempenhar bem a sua função.

A ética do contribuinte está relacionada a conduta da pessoa jurídica ou da pessoa física (sujeitos passivos) ao se organizar tributariamente para efetuar o pagamento do tributo.

Para compreensão do tema, importante é a lição de Marco Aurélio Greco:

não é de hoje que o relacionamento entre Fisco e contribuinte tem se caracterizado: de um lado, pela constante busca de maior eficácia na aplicação das leis visando obter a maior arrecadaçáo possível e, de outro lado, por uma preocupação dos agentes econômicos no sentido de se verem onerados com a menor carga tributária legalmente admissível.

Atualmente a relação fisco-contribuinte é uma constante tensão: de um lado o Estado arrecadador, que a cada ano implementa e aperfeiçoa os mecanismos de cruzamento de informaçôes e fiscalização com o intuito de combater a sonegação fiscal; de outro, o contribuinte que se sente lesado pela alta carga tributária imposta e que por isso, busca formas lícitas (elisão fiscal) ou ilícitas (evasão) para diminuir o pagamento do tributo.

Se a evasão refere-se a adoção de condutas ilícitas para se furtar ao pagamento do tributo, não resta dúvida de que tal prática fere o dever ético do contribuinte de pagar aquilo que lhe é imposto, pois, ao sonegar o tributo, seja pela falsificação de uma declaração, seja pela náo emissão de um documento fiscal, ou qualquer outra conduta que se possa pensar, o sujeito passivo demonstra a falta de comprometimento com toda a sociedade.

Em contrapartida, a elisão fiscal se insere numa seara de organização, de planejamento, que tem como objetivo não a prática de ilícitos para evadir-se do dever de pagar tributo, mas sim o estudo das normas tributária com o objetivo de aplicar aquela que seja mais benéfica/econômica para o seu negócio. É neste contexto que se insere o que chamamos de "planejamento tributário".

Segundo Marco Aurélio Greco ${ }^{8}$ : “o 'planejamento' é a atividade exercida pelo contribuinte, enquanto 'elisão' é o efeito de submeter-se a uma menor carga tributária, obtido pelo planejamento".

O planejamento tributário, assim como a evasão fiscal tem como objetivo eliminar, reduzir ou mesmo postergar o pagamento do tributo, todavia, a diferença reside que no

7 GRECO. Marco Aurélio. Planejamento Tributário, 2011.

8 GRECO. Marco Aurélio. Planejamento Tributário, 2011, p. 63. 
planejamento tributário os meios necessários para alcançar tais resultados estão dispostos na própria norma ao passo que o da evasão refere-se a práticas ilegais, e portanto, não tuteladas pelo ordenamento jurídico.

Todavia, a adoção de planejamentos tributários que visem a diminuição de carga tributária, em muitos casos tem sido objeto de questionamentos pelo fisco, por representarem uma operação adotada com o único e exclusivo intuito de diminuir o tributo, ou seja, se o negócio realizado não teve outra finalidade que não a diminuição do tributo, tal conduta é considerada como abuso de direito do contribuinte e passível de autuação.

Entendimentos como esses são mais constantes entre os agentes do fisco, conforme observa Marco Aurélio Greco: "se determinada operação ou negócio privado tiver por efeito reduzir carga tributária, mas se apoia num motivo empresarial, o direito de auto -organização terá sido adequadamente utilizado. Não haverá abuso! O fisco nada poderá objetar!”. (2011, p. 213)

Logo, o planejamento tributário ainda que licitamente adotado pode ser questionado pelo fisco, quando realizado exclusivamente com o objetivo de reduzir a carga tributária (abuso de direito, por exemplo), entretanto, se a conduta foi adotada tendo como base as brechas deixadas pela própria norma, não há conduta antiética, não há evasão, não há sonegação e sim elisão.

Quem se comporta de modo a não preencher o tipo legal e por esse meio evita [vermeidet] a conseqüência jurídica 'imposto', não age ilegalmente. Todo cidadão pode organizar-se de modo a pagar menos tributos possíveis. A elisão fiscal consciente, planejada é uma forma legal de resistência fiscal. Ela não é imoral. Isso é provavelmente reconhecido em todos os Estados de Direito que respeitam a liberdade. (TIPKE, 2012, p. 111)

Isso coloca em xeque a segurança jurídica pretendida pelo contribuinte, pois, embora se tenha buscado licitamente alternativas para reduzir a carga tributária, o seu procedimento pode ser questionado pelo fisco, tendo que em muitos casos que buscar a tutela jurisdicional para se resguardar.

Todas essas distorçôes levam muitos contribuintes a se questionarem se devem pagar tanto tributo. Esses pensamentos são motivados por diversas circunstâncias, que podemos resumir nos seguintes sentimentos vivenciados pelos contribuintes que se sentem prejudicados:

a) Se muitos não pagam corretamente o tributo, porque eu devo pagar?

b) O Estado concede uma série de incentivos para determinados contribuintes sem observância da capacidade contributiva. Porque tenho que recolher por eles?

c) com tantas normas publicadas, não há como o fisco fiscalizar todos os fatos tributários. 
d) para que pagar corretamente tributo se o Estado náo aplica onde devia.

Esses questionamentos são apenas alguns de tantos outros que perseguem o contribuinte no seu dia-a-dia, influenciado as suas condutas para o bem ou para o mal.

O que o contribuinte necessita é segurança jurídica nas suas operações, todavia, com a avalanche de normas editadas diariamente e entendimentos diversos exarados pelo próprio fisco, fica difícil se organizar de tal forma a ter esta segurança sobre um fato realizado hoje que pode ser questionado no futuro.

De acordo com TIPKE um agir moral-tributário deficiente é reflexo da deficiente moral-fiscal do Estado, pois, um fenômeno implica no outro. E ainda ressalta o próprio autor": "não se trata aqui desde logo da questão, se uma moral impositiva incorreta do Estado pode justificar uma moral do contribuinte incorreta, mas sim se aquela, faticamente, influencia a do contribuinte". (2012, p. 07)

Logo, as atitudes imorais do Estado não podem servir de justificativa para que o contribuinte não haja eticamente recolhendo os tributos devidos para os cofres públicos; todavia, o que ocorre é que a ineficiência do Estado, desvios do dinheiro público, falta de comprometimento de agentes políticos, favores fiscais concedidos a determinada classe de contribuintes por meio de regimes fiscais, muitas vezes acobertados por agentes públicos, tendem a influenciar outros contribuintes a se furtarem do pagamento dos tributos. (MACHADO, 2014, p. 56)

Por isso a exigência do tributo não pode ser vista apenas pelo seu aspecto negativo, no sentido de uma tributação elevada, mas sim como uma fonte necessária para implementar as políticas públicas asseguradas pela própria constituição, tais, como saúde, segurança, educação, entre outras.

No presente estudo, procuramos identificar o principio da moralidade destinado aos agentes do Estado, e não o agir moral ou imoral do contribuinte. Isto simplesmente porque o artigo 37 da Constituiçáo destina-se à administração. Não defendemos a atitude imoral-tributária do contribuinte, contudo é possível sustentar que a atitude imoral do Estado pode causar, além do dano em si, reflexos na conduta do contribuinte.

Prevê o CTN que:

Art. 3o Tributo é toda prestação pecuniária compulsória, em moeda ou cujo valor nela se possa exprimir, que não constitua sanção de ato ilícito, instituída em lei e cobrada mediante atividade administrativa plenamente vinculada.

9 Segundo GRECO, hoje temos de enxergar a tributação sob a ótica da proteção da propriedade, mas também (por isso digo acrescer e não substituir) como instrumento de viabilização das mudanças econômicas e sociais que a Constituição prevê, em especial a implementação das políticas públicas à vista da realidade. $(2011$, p. 63$)$ 
Destacando a última parte do artigo, notamos que a cobrança do tributo, mesmo não admitindo discricionariedade, é ato administrativo, ou seja, está evidentemente sujeita ao princípio da moralidade.

De todo modo, entendemos que o exame da ética (moral) fiscal, portanto, tem por objetivo analisar a conduta do Estado na instituição e na arrecadação do tributo.

O princípio da capacidade contributiva é o único princípio fundamental, que é adequado a todos os direitos fundamentais de Constituiçóes de Estados de Direito Social”, pois, todo contribuinte deseja ser tributado dentro do limite do que ele pode dispor, não comprometendo assim o mínimo necessário para a sua própria existência. (TIPKE, 2012, p. 20)

O já citado princípio da capacidade contributiva ainda que no texto constitucional se utilize a expressão "sempre que possível", deve ser entendido como obrigatório na medida em que não havendo capacidade para contribuir, ou dizendo de outro modo, onde o patrimônio do contribuinte se revelar necessário para o mínimo que lhe permita subsistir, não deverá ocorrer a tributação, pois, faltaria ao ente tributante aptidão para exigir a tributação sobre o mínimo necessário para a manutenção da pessoa e da sua família.

Neste contexto e com base na "reserva do possível" independentemente da autonomia dos Estados é certo que estes possuem o dever de implementar políticas públicas para combater a pobreza e promover uma existência digna, ou seja, não se pode exigir que o contribuinte contribua além das suas possibilidades financeiras, pois, desta forma o Estado estaria colaborando para aumentar ainda mais as desigualdades.

Por isso é importante que os legisladores tenham consciência do seu papel de representantes dos interesses dos cidadãos, e não dos seus próprios interesses, todavia, em importante análise sobre os limites da imposição fiscal destaca Klaus TIPKE:

Aos Parlamentos foi um dia incumbida a missão de proteger os cidadãos contra tributos elevados ou exagerados. Hoje não defendem mais - assim é frequentemente criticado ou lamentado - os Parlamentos o ideal do Estado austero; eles se tornaram, pelo contrário, o motor das crescentes prestaçóes públicas - e com isto necessariamente comprometidos com altos tributos. (2012, p. 45)

Os dados de organizaçóes não governamentais procuram incessantemente, e com frequente êxito, demonstrar que os recursos arrecadados pelo Estado por meio dos tributos são mal empregados ${ }^{10}$, ou seja, o Estado está em débito com o cidadão, que a cada dia se convence que falta ética na gestáo dos tributos arrecadados.

10 Entre os 30 países com a maior carga tributária (arrecadação em relação ao PIB), o Brasil continua sendo o que proporciona o pior retorno dos valores arrecadados com impostos em prol do bem estar da sociedade, aponta estudo divulgado nesta quarta-feira (3) pelo Instituto Brasileiro de Planejamento Tributário (IBPT). Acesso em: <http:/g1.globo.com/economia/noticia/2014/04/brasil-se-mantem-como-o-pais-com-o-piorretorno-de-aplicacao-de-impostos.html $>$ Acesso em 01/08/14. 
Além da incredulidade do contribuinte em relação a ética do fisco na arrecadação do tributo, há ainda um descontentamento em relação a excessiva quantidade de normas que são editadas todos os dias, tornando a difícil tarefa de apurar os tributos, ainda mais árdua.

Conforme elucida TIPKE: "já desde os anos setenta e oitenta multiplicam-se por isso as manifestaçóes de juízes superiores, advogados e cientistas, que descrevem o vigente Direito Tributário como 'caos', 'selva' ou até mesmo 'perversão’”. (2012. P. 74)

Toda norma tributária quando publicada traz consigo uma série de incertezas e dúvidas em relaçáo ao seu texto. A pergunta que se faz é: qual o objetivo do legislador ao publicar uma lei truncada ou mal redigida? Importante lembrar que uma norma mal redigida não só coloca em dúvida o contribuinte, como também os agentes públicos que devem fiscalizá-la e aplicá-la, gerando um verdadeiro conflito entre fisco e contribuinte, além de autuaçóes arbitrárias e inconsistentes. ${ }^{11}$

É exatamente o que ocorre nos dias atuais: o contribuinte, os agentes do fisco, e até mesmo os juristas sentem dificuldade na interpretação de diversas normas tributárias.

Nesta medida, diante dessa complexidade do sistema, a falta de transparência na interpretação da lei tributária dada pelos Agentes da administração, a garantia de liberdade na organização dos seus negócios privados, segundo Heleno Torres, feriria o princípio da boa administração e em consequência o princípio da Confiança Legítima. (2011, p. 202. nota 69)

E ainda tratando sobre a dificuldade de interpretação e elaboração das normas tributárias, Klaus VOEGEL registra que são os princípios jurídicos em que se baseiam nossas leis tributárias, ou melhor: em que deveriam basear-se, em grande extensão não mais salvaguardados, tornados irreconhecíveis. Eles foram por um sem número de alteraçóes e complementaçóes tâo sobrepostos e deformados por exceções e novamente exceçóes a essas exceçóes, que para os atingidos não mais reconhecíveis como tentativas de uma distribuição justa de carga tributária. (apud TIPKE, 2012, P. 74)

As considerações feitas por VOEGEL retratam uma realidade, pois, com tantas normas publicadas e alteradas, o contribuinte se vê compelido a buscar auxílio para interpretação e aplicação da lei vigente, a fim de obter segurança jurídica, todavia, em muitos casos isso não lhe trará a necessária de certeza que está pagando corretamente o tributo.

11 Conforme observa Francesco Carnelutti: [...] mas o que pode fazer um cidadão, hoje, para conhecer todas as leis do seu país? Não se trata mais somente do homem da rua; hoje, até mesmo os juristas, não estão em condições de conhecer mais do que uma pequena parte delas. $\mathrm{O}$ ordenamento jurídico, cujo maior mérito deveria ser a simplicidade, transformou-se, para nossa desgraça, em um complicado labirinto, no qual, até os que deveriam ser os guias, perdem-se. (2008. p. 47) 
O desvio legislativo decorre em grande parte de que, no processo de elaboração da lei, prevaleçam interesses particulares sobre o interesse geral. E ainda tratando a respeito das injustiças que ocorrem dentro do sistema político RAWS ressalta que o poder político rapidamente se acumula e se torna desigual; e, servindo-se do aparelho coercitivo do Estado e de suas leis, aqueles que conseguem a predominância podem muitas vezes garantir para si mesmos uma posição privilegiada. (2002, p. 47)

Tudo isso leva o cidadão, nas palavras de TIPKE "a não confiar mais na competência do poder legislativo para a solução dos grandes problemas do país, inclusive uma grande reforma tributária”. É exatamente esse sentimento de insegurança que permeia a relação jurídica tributária nos dias atuais entre o fisco e o contribuinte. E ainda ressalta o autor: "a moral tributária não exige, que as leis tributárias tenham uma tradição, mas que elas se harmonizem com a Constituição atual e com a Ética corporificada em seus direitos fundamentais", pois, assim como os cidadãos o próprio Estado é submisso a Constituição. (2012, p. 77-79)

Mesmo na relação entre os Estados pode haver quebra da confiança legítima. Para Heleno Torres, a sua perda (de confiança) pode se dar até mesmo entre entes da federação, no cumprimento de convênios, por exemplo, destacando que a manifestação da vontade interestatal deve amparar-se em confiabilidade, até porque a quebra da confiabilidade pode ter repercussóes severas também sobre a esfera jurídica dos contribuintes.

É preciso observar que a administração pública, no exercício da fiscalização e arrecadação de tributos cada vez mais exerce sua função normatizadora. Significa que uma enorme quantidade de normas internas, regulamentadoras das leis e decretos (estes também enquadrados no rol de atividade normativa do administrador) que deveriam dirigir-se unicamente aos próprios agentes administrativos para orientá-los no cumprimento das mesmas leis e decretos, dirigem-se diretamente aos contribuintes, frequentemente inovando o ordenamento jurídico com novas obrigaçóes tributárias acessórias e até principais, essas ultimas, naturalmente, de forma velada.

Os decretos em matéria tributária, que também deveriam restringir-se ao conteúdo da lei que lhes dá fundamento, não raramente inovam, como se vê nos Regulamentos do ICMS nos Estados, por exemplo. Mesmo que seja para conceder isençóes (que os contribuintes não costumam questionar) essa prática é fragrantemente inconstitucional, mas não tem sido incomum.

A doutrina, inclusive estrangeira, há tempos também percebe tal tendência. Alejandro Altamirano, publicou artigo denominado "Jaque a la ley", significando o correspondente, ao jargão em português, de que a "Lei está em xeque"(!).

Com precisão, ALTAMIRANO pontua que: 
Por la incoherencia que muestra muchas veces la ley, por las contradicciones evidente entre varios preceptos normativos entre sí, por la exigencia de la reglamentación de una norma so pretexto de que su operatividad devendrá de la pertinente reglamentación, el ordenamiento - como conjunto sistemático y orgánico - pierde sentido, se pulveriza.

E conclui:

Indudablemente, los principios - que inspiran a la ley - son impermeables a la acción humana y más confiables. Pero también requiere de operadores jurídicos comprometidos con búsqueda de la verdad y que prescindan del realtivismo proprio de nuestro tiempo. (in Marquez et al, 2010. P. 345-346)

Não se quer afirmar, categoricamente, especialmente considerando a concepçáo positivista metódica-axiológica de TORRES, que a lei teria seu critério de validade adstrito à condição moral a que esta mesma lei foi concebida, por parte do legislador. Contudo, na busca do conteúdo e alcance do princípio da moralidade fatalmente nos deparamos com standarts morais expressos no ordenamento, independentes, e que estáo inseridos no princípio da confiança legítima. Ora, se a moralidade decorre da boa administraçáo e da confiança legítima, então há uma moralidade interna no direito que não pode ser negada. Lon L. Fuller, em sua obra The Morality of Law, reconhece que a lei, para que seja perfeita (não necessariamente para que seja válida formalmente) deve atender cumulativamente a oito requisitos (eight ways to fail to make law):

1) generalidade;

2) serem promulgadas;

3) prospectivas;

4) claras e compreensíveis;

5) não contraditórias;

6) não exigir o impossível;

7) serem atualizadas;

8) serem coerentes com a ação estatal ${ }^{12}$; (FULLER, 1969. P. 33-37)

Desta feita, para o positivismo hermético, basta o cumprimento do $2^{\circ}$ requisito, entendido como o cumprimento do correspondente processo legislativo e os princípios inerentes a sua instituição (em matéria tributária, os correspondentes aos limites constitucionais ao

12 Tradução livre. 
poder de tributar, que efetivamente abarcam também os itens $1^{\circ}$ e $3^{\circ}$ da lista) para que a norma seja válida.

Contudo, é provável que mais desses requisitos, não necessariamente todos, mas outros além dos três primeiros, como o $4^{\circ}$, o $5^{\circ}$ ou o $8^{\circ}$, por exemplo, também sejam necessários, sob pena de irregularidade da norma por ferimento a confiança legitima.

O mesma ofensa a confiança legítima se observa a sequencia, quase que anual, de anistias tributárias ou parcelamentos incentivados, prestigiando o contribuinte mal intencionado e especialmente aquelas que são aprovadas justamente em tempos de eleiçóes. No Brasil, de 1999 para cá, esses parcelamentos incentivados passaram a ser popularmente conhecidos como "REFIS" (REFIS 1, 2, 3..., REFIS municipal, estadual etc), em referência ao primeiro deles, editado em 1999 pelo governo federal. Com essas anistias rotineiras, muitos contribuintes deixam de pagar tributos de forma também rotineira, sabendo que cedo ou tarde virá o perdão ou a moratória, desistimulando aqueles que pretendem pagar em dia. Fazendo as contas, estes percebem que pagaram mais do que poderiam ter pago assumindo tal conduta viciada.

A chamada "Guerra Fiscal", em que Estados se digladiam para oferecer condiçóes vantajosas a despeito de Estados vizinhos, agindo em flagrante atitude antiética, seja com relação ao outro Estado, quanto à boa-fé do contribuinte. Não há um Estado da federação que não critique o vizinho, mas ao mesmo tempo estabelece - via Decreto - incentivos e benefícios fiscais dos mais criativos, agindo de forma idêntica, sob o manto do Princípio Federativo, mas sabendo claramente que sua conduta é frontalmente ofensiva a Constituiçao Federal. O contribuinte, que neste caso deveria ser mero expectador, arca com as diferenças financeiras de um Estado a outro, e muitas vezes também age aproveitando-se de créditos que foram concedidos à margem da lei e da ética, sem reconhecer a "imoralidade" do benefício que lhe é concedido.

A utilização de subterfúgios para a cobrança da dívida tributária, como a indevida inclusão de sócios no polo passivo das execuções fiscais por parte das procuradorias da fazenda pública sem processo administrativo prévio, como meio de coagir a empresa ao pagamento, isso quando esse procedimento não vem acompanhando de uma denúncia penal tributária, apostando no pânico causado a diretores e sócios, mais uma vez quase que obrigados a pagar, mesmo diante de cobranças eventualmente indevidas ou abusivas.

E os pagamentos indevidos de tributo? Porque a restituição de tributos deve ser exercida expressamente pelo contribuinte, mesmo nos casos que o sistema de informática da Receita, no cruzamento constante de informaçóes, muitas vezes identifica o excesso? Será que o justo não seria que o fisco, identificando tal ocorrência, não deveria - de ofício - restituir o valor pago a maior? Pode parecer absurdo, mas é preciso lembrar sempre que o Estado está constantemente sujeito ao principio da legalidade e também à moralidade, 
e não deveria ser surpresa para o cidadão atitudes como essa, legitimando ainda mais a tributação.

De todo modo, não só buscando um ponto de consenso, como também uma inflexão aos ditames positivistas excludentes, concluímos, com as palavras de Maurice Hauriou, citadas por FRANCO SOBRINHO (1974, prefácio) que teriam sido ditas há exatamente um século atrás (1914): a lei é sempre moral, pode contudo não ser moral sua aplicação.

\section{Conclusões}

A legitimidade do poder fiscal, no Estado Democrático de Direito, é obtida por meio do parlamento reunido em assembleias baseadas no principio do consentimento. $\mathrm{O}$ indivíduo, por seu turno, tem deveres para com a comunidade, fora da qual não é possível o livre e pleno desenvolvimento da sua personalidade. No exercício destes direitos e no gozo destas liberdades ninguém está sujeito senão às limitaçóes estabelecidas pela lei com vistas exclusivamente a promover o reconhecimento e o respeito dos direitos e liberdades dos outros e a fim de satisfazer as justas exigências da moral, da ordem pública e do bem -estar numa sociedade democrática. Esta dicção é extraída do artigo 29 da Declaração Universal dos Direitos do Homem, plenamente aplicável em matéria de Justiça Fiscal.

A postura meramente arrecadatória do Estado, por exemplo, revela ofensa a Moralidade Pública no âmbito tributário, na medida em que não atende aos objetivos de igualdade entre contribuintes e os aspectos sociais do tributo. E aqui não se trata apenas de separar claramente os tributos chamados "fiscais" dos "extrafiscais". Sabemos que todo o "tributo fiscal" tem também finalidades extrafiscais, não meramente arrecadatórias. Veja-se o caso do ICMS, que, como vimos acima, ao serem estabelecidas alíquotas diferenciadas em razão da essencialidade do produto, o legislador também o faz para inibir ou estimular o consumo de determinadas mercadorias ou serviços. É o caso, por exemplo, das bebidas alcoólicas e dos cigarros. O mesmo ocorre com o IPI em relaçáo a esses mesmos produtos. Imaginemos que o objetivo extrafiscal desse tributo seja exitoso, ou seja, todos parem de consumir ou produzir bebidas alcoólicas ou cigarros imediatamente. A função extrafiscal é atingida, mas a função fiscal será imediatamente afetada, pois é grande a arrecadação proveniente destes produtos no Brasil, e os governos seguramente contam com isso no seu orçamento, o que é um paradoxo. Por isso, independentemente da finalidade fiscal ou extrafiscal, a conduta do Estado deve privilegiar sempre a moral tributária, não simplesmente a arrecadação.

Outro exemplo é a alta complexidade da sistemática de determinados tributos vigentes (ICMS, COFINS), dificultando e desvirtuando quase que completamente a sua origem e matriz constitucional, tornando-o irreconhecível. Tal mutação revela atuação do Estado à margem da moralidade, pois induz o contribuinte ao erro. Certa vez, a visitar 
o Brasil, afirmou o jurista espanhol Jose Juán Ferrero Lapatza que é mais fácil pescar em águas turvas, referindo-se a infinidade de normas tributárias vigentes e crescentes a cada dia, a perplexidade do cidadão diante disso, que na dúvida paga mais tributo do que deve.

Pois bem. Todo esse contexto social e jurídico nos leva a concluir que o Estado, de forma ampla, está sujeito a observância do principio da moralidade e, náo raramente, o ofende. Quanto maior a ofensa ao principio da moralidade, menor será a legitimidade do Estado em exigir esta ou aquela conduta do contribuinte, ou até mesmo questioná-la.

Contudo, não basta a exaustiva constataçáo sem que possamos reclamar a tutela do Estado, por meio do poder judiciário especialmente, para a garantia do exercício desses direitos. Também vimos que náo é producente a busca de elementos na subjetividade do julgador, elementos que estejam completamente fora do ordenamento jurídico vigente, sob pena de são sabermos ao fim e a cabo que ética será aplicada.

É preciso dar objetividade e previsibilidade na aplicação do principio da moralidade, e isto só é possível sob o manto da Segurança Jurídica. É preciso que uma acepção positivista excludente da moral como condição prévia de validade da norma, mas que por outro lado, privilegie os valores constantes na Constituição.

Esta concepção, sem dúvida, se coaduna com o positivismo metódico-axiológico de Heleno Torres, que, conforme visto no desenvolvimento do trabalho trata a questão da moralidade como integrada ao principio da boa administração e da confiança legítima, apresentadas por Torres como sendo, finalmente, princípios decorrentes do principio-garantia da Segurança Jurídica.

\section{Referências}

ALTAMIRANO, Alejandro. Jeque a la ley. In Libro homenaje a Luis Hernandes Berenguel. Marquez, Jaime Lara (coord.) et al. Lima: PUC Perú, 2010.

ARISTOTELES. Etica a Nicomaco. Trad. Edson Bini. São Paulo: Edipro, 2013.

BANDEIRA DE MELLO, Celso Antônio. O Conteúdo jurídico do princípio da igualdade. São Paulo: Ed. Revista dos Tribunais, 1978.

BARROSO, Luís Roberto. Curso de direito constitucional contemporâneo: os conceitos fundamentais e a construção do novo modelo. 2 ed.. São Paulo: Saraiva, 2010.

BECKER, Alfredo Augusto. Teoria geral do direito tributário. 3. ed. São Paulo: Lejus, 1998.

. Carnaval tributário. 2 ed. 1 reimpr. São Paulo: Lejus, 2004.

BOBBIO, Norberto. Teoria do ordenamento jurídico. 10 ed. Brasília: UnB, 2006. 
Da estrutura à funçáo: novos estudos de teoria do direito. Barueri, SP: Manole, 2007.

BRANDÃO. Antônio José. Moralidade administrativa. Revista de Direito Administrativo. v. 25. Rio de Janeiro, Renovar, jul./set. de 1951.

BOUVIER, Michel. A questáo do imposto ideal. In Princípios e limites da tributação 2. Coord. Roberto Ferraz. São Paulo: Quartier latin, 2009.

CANARIS, Claus-Wilhelm. Pensamento sistemático e conceito de sistema na ciência do direito. 2 ed. Lisboa: Calouste Gulbenjian, 1996.

CANO, Roberto M. J. Una metateoria del positivismo jurídico. Madrid: Marcial Pons, 2008.

CARNELUTTI. Francesco. Como nasce o direito. 4. ed. Campinas: Russell Editores, 2008.

CARRAZZA, Roque Antonio. Curso de direito constitucional tributário. 26 ed. rev. ampl. São Paulo: Malheiros, 2010.

COELHO, Sacha Calmon Navarro. Curso de Direito Tributário. 9. ed. Rio de Janeiro: Forense, 2007.

COMPARATO. Fábio Konder. Ética. Direito, moral e religiaao no mundo moderno. São Paulo: Cia das Letras, 2006.

CRUZ, Alvaro Ricardo de Souza. Habermas e o Direito Brasileiro. 2 ed. Rio de Janeiro: Lumen Iuris, 2008.

DINAMARCO, Candido Rangel. A Instrumentalidade do Processo. 12 ed. São Paulo: Malheiros, 2005.

FERRAZ JR., Tercio Sampaio. Conceito de Sistema no Direito. Uma investigação histórica a partir da obra jusfilosófica de Emil Lask. São Paulo. Ed. Revista dos Tribunais, 1976.

, Tercio Sampaio. Introduçáo ao estudo do Direito. 4 ed. rev. ampl. São Paulo, Atlas, 2003.

FRANCO SOBRINHO, Manoel de Oliveira. O controle da moralidade administrativa. Sáo Paulo: Saraiva, 1974.

FULLER, Lon L. Morality of law. Revised edition. Yale: Yale University, 1969.

GRAU, Eros Roberto. A Ordem econômica na constituiçáo de 1988. 3 ed. São Paulo: Malheiros, 1997.

. Porque tenho medo dos juízes? 6 ed. São Paulo: Malheiros, 2013. 
GODOY, Claudio Luiz Bueno de. Funçáo social do contrato: os novos princípios contratuais. São Paulo: Saraiva, 2004.

GRECO. Marco Aurélio. Planejamento tributário. 3 ed. São Paulo: Dialética, 2011.

GUSMAO. Paulo Dourado de. Filosofia do direito. Rio de Janeiro: Forense, 1985.

HABERMAS, Jürgen. Direitos e Democracia. Rio de Janeiro: Tempo Brasileiro. 1997.

HART, Hebert Lionel Adolphus. O conceito de Direito. Lisboa: Gulbenkian, 1961.

HEGEL, Georg Wilhelm Friedrich. Princípios da Filosofia do Direito. trad. Orlando Vitorino. São Paulo: Martins Fontes, 1997.

JUSTEN FILHO, Marçal. Principio da moralidade pública e o direito tributário. In Revista de Direito Tributário. Sáo Paulo, v. 67. 1996.

KELSEN, Hans. Teoria pura del derecho. Trad. Roberto Vernengo. México DF: Universidad de México, 1982.

. Teoria geral das normas. Trad. José Florentino Duarte. Porto Alegre: Sérgio Antonio Fabris, 1986.

. O problema da justiça. Trad. João Baptista Machado. São Paulo: Martins Fontes, 1993.

. Teoria geral do direito e do estado. Trad. Luis Carlos Borges. São Paulo: Martins Fontes, 2000.

LEITER, Brian. Naturalismo y teoría del derecho. Madrid: Marcial Pons, 2012.

MACHADO, Hugo de Brito. Segurança jurídica e a questáo da lei complementar. In Direito tributário e ordem econômica. Coord. Heleno Taveira Torres. São Paulo: Quartier Latin, 2010.

MACHADO, Graziela. Ética na relação fico-contribuinte. Francisco de Assis e Silva (Coord). In Curitiba: Instituto Memoria, 2014.

MARCONDES, Sylvio. Enciclopédia saraiva de direito. v.20. São Paulo: Saraiva, 1985.

MARTINS, Ives Gandra da Silva; BASTOS, Celso Ribeiro. Comentários à constituiçáa do Brasil. 1 ed. 7 v. São Paulo: Saraiva, 1990.

. Uma teoria do tributo. In O Tributo: Reflexão multidisciplinar sobre sua natureza. Rio de Janeiro: Forense, 2007.

MARTINS, José Salgado. A funçáo criadora da jurisprudência. In Estudos em Homenagem a Miguel Reale. Organizador Teófilo Cavalcanti Filho. Ed. Revista dos Tribunais: São Paulo, 1977.

MELlO, Celso Antônio Bandeira de. Curso de Direito administrativo. 26 ed. rev. ampl. São Paulo: Malheiros, 2009. 
MORA, Jose Ferrater. Diccionario de Filosofía. 5 ed. Buenos Aires: Sulamericana editorial, 1964.

NORONHA, Fernando. O direito dos contratos e seus princípios fundamentais: autonomia privada, boa-fé, justiça contratual. São Paulo: Saraiva, 1994.

PERLINGIERI, Pietro. Manuale di Diritto Civile. $2^{a}$ ed. Napoli: Edizioni Scientifiche Italiane, 2000.

PIETRO, Maria Sylvia Zanella Di. Direito administrativo. 24 ed. São Paulo: Atlas, 2011.

RAWLS, John. Justiça e Democracia. Trad. Irene Paternot. São Paulo: Martins Fontes, 2002.

REALE, Miguel. Filosofia do direito. 19 ed. São Paulo: Saraiva, 2002.

. O direito e a vida dos direitos. 5 ed. anot. Atual. Por Ovídio Rocha Sandoval. São Paulo: Ed. Revista dos Tribunais, 1999.

A Doutrina de Kant no Brasil. São Paulo: Saraiva, 1949.

RIPERT, Georges. A regra moral nas obrigaçóes civis. Campinas - Bookseller, 2002.

RODRIGUES, Sílvio. Direito civil. Parte geral. v. 1. 21 ed. atual. São Paulo: Saraiva, 1990.

ROSS, Alf. Direito e Justiça. 2 ed. Trad. Edson Bini. São Paulo: Edipro, 2007.

SMITH, Adam. Teoria dos sentimentos morais. Trad. Lya Luft. São Paulo: Martins Fontes, 2002.

SILVA, De Plácido e. Vocabulário jurídico. 11 ed. 1 v. Rio de Janeiro: Forense, 1989.

SILVA, José Afonso. Curso de direito constitucional positivo. $12 \mathrm{ed}$. rev. atual. São Paulo: Malheiros, 1996.

. Aplicabilidade das normas constitucionais. São Paulo, RT, 1982.

TEPEDINO, Gustavo. A parte geral do novo Código Civil/Estudos na perspectiva civil constitucional. Rio de Janeiro: Renovar, 2002.

TEODORO JR. Humberto. As reformas do direito processual civil e o principio da segurança jurídica. In $\mathrm{O}$ processo na constituição. Coord. Ives Gandra da Silva Martins e Eduardo Jobim. São Paulo: Quartier Latin, 2008.

TIPKE, Klaus; YAMASHITA, Douglas. Justiça fiscal e princípio da capacidade contributiva. São Paulo: Malheiros, 2002.

. Moral Tributária Del Estado y de los Contribuyentes. Madri: Marcial Pons, Ediciones Jurídicas e Sociales, S.A. 2002. 
. Moral tributária do estado e dos contribuintes. Luiz Doria Furquim (trad). Porto Alegre: Fabris, 2012.

TORRES. Heleno Taveira. O poder judiciário e o processo tributário: divergência jurisprudencial e a coisa julgada nas relaçóes tributárias continuativas. In Separação de poderes e efetividade do sistema tributário. Belo Horizonte, Del Rey, 2010.

Direito Constitucional Tributário e segurança jurídica. São Paulo: Revista dos Tribunais, 2011.

Direito Constitucional Financeiro. Sáo Paulo: Revista dos Tribunais, 2014.

TORRES, Ricardo Lobo. Normas de interpretaçáo e integração do direito tributário. 4 ed rev. atual. Rio de Janeiro: Renovar, 2006. 